Сліссева О.К. доктор економ. наук, професор, ORCID ID: 0000-0003-0167-2418

Гільорме Т.В. канд. економ. наук, ORCID ID: 0000-0001-6878-1630 Дніпропетровський національний університет імені Олеся Гончара

\title{
ПЕРСПЕКТИВИ ІМПЛЕМЕНТАЦІЇ МОДЕЛІ ПОВЕДІНКИ АГЕНТІВ 3 ПИТАНЬ ЕНЕРГОЗБЕРЕЖЕННЯ
}

\section{ПЕРСПЕКТИВЫ ИМПЛЕМЕНТАЦИИ МОДЕЛИ ПОВЕДЕНИЯ АГЕНТОВ ПО ВОПРОСАМ ЭНЕРГОСБЕРЕЖЕНИЯ}

\section{PERSPECTIVES OF IMPLEMENTATION BEHAVIOR PATTERNS AGENTS ON MATTERS ENERGY CONSERVATION}

У статті розглянуто бар'єри групових інтересів агентів при впровадженні енергозберігаючих технологій: комунікачійні, промислові та технічні. Запропоновано використання агентно-орієнтованого моделювання для визначення параметрів стану активності поведінки агентів. Запропоновано групування агентів за ступенем зачікавленості до прочесів з енергозбереження. Побудовано математичні залежності переходу ицих груп агентів на засадах теорії клітинних автоматів (КА). На основі концепиіі еволюиї екосистем агентів проаналізовано принщипи побудови системи управління впровадження енергозберігаючих технологій. Розглянута можливість впровадження моделі поведінки агентів з питань енергозбереження в контексті конщепщії «хижакжертва», щуо обумовлено принщипами економічної дочільності поведінки агентів та наявними інноваційними енергозберігаючими технологіями. Розглянута модель поведінки агентів дозволить посилити контроль та вплив на групи агентів, які приймають управлінські рішення щчодо доцільності заходів щчодо просування технологій 3 енергозбереження.

Ключові слова: енергозбереження, агент, клітинний автомат, економічна поведінка, система «хижак-жертва»

В статье рассмотрены барьеры групповых интересов агентов при внедрении энергосберегающих технологий: коммуникационные, промышленные и технические. Предложено использование агентно-ориентированного моделирования для определения параметров состояния активности поведения агентов. Предложено группировка агентов по степени заинтересованности $\kappa$ процессам по энергосбережению. Построены математические зависимости перехода этих групп агентов на основе теории клеточных автоматов (КА). На основе концепчии эволючии экосистем агентов проанализировань принципь построения системы управления внедрения энергосберегающих технологий. Рассмотрена возможность внедрения модели поведения агентов по вопросам энергосбережения в контексте концепциии «хищник-жертва», что обусловлено принципами экономической целесообразности поведения агентов и имеющимся 
инновационными энергосберегающими технологиями. Рассматриваемая модель поведения агентов позволит усилить контроль и влияние на группы агентов, которые принимают управленческие решения относительно изелесообразности мероприятий по продвижению технологий энергосбережения.

Ключевые слова: энергосбережение, агент, клеточный автомат, экономическое поведение, система «хищник-жертва»

The article examines barriers agents of group interests while implementing energy saving technologies: communications, industrial and technical. Offered to use agent-based modelling for definition of parameters of the activity behaviour of agents. Offered grouping of agents according to the degree interest in the processes of energy saving. The mathematical dependence conversion of these groups of agents based on the theory of cellular automata (CA). Based on the concept of evolution of ecosystems agents analysed principles of construction management energy saving technologies. Offered the possibility of introducing behaviour patterns of agents energy savings in the context of the concept of "predator-victim», which is due to principles of behaviours of economic expediency agents and existing innovative energy saving technologies. Offered the model of behaviours allow to strengthen control and impact on the of agents who are taking on managerial feasibility of measures to promote of energy saving technologies.

Keywords: energy saving agent, cellular automata, economic behaviour, system of "predator-victim"

Вступ. При впровадженні енергозберігаючих технологій особливе місце посідає проблема взаємодії та взаємовідносин об'єднань людей, яка є проявом групових інтересів. Групи інтересів виникають на основі об'єктивно існуючих проблем та потреб людей при рішенні питань використання альтернативних джерел енергії 3 метою підвищення енергоефективності технологій генерування, споживання, транспортування, перерозподілу та ін. Для формування груп та ефективної взаємодії необхідне дослідження механізмів активізації їх взаємодії, доцільної діяльності в рамках реалізації їх інтересів. Для вирішення таких питань необхідно аналізування особливостей взаємодії групових інтересів при впровадженні енергозберігаючих технологій.

Визначення особливостей i тенденцій групових інтересів при впровадженні енергозберігаючих технологій використання енергії альтернативних джерел на сьогодні $є$ актуальним. У наукових літературних джерелах означена специфічність інтересів деяких груп енергоефективних технологій використання альтернативних джерел енергії. Т. Сааті 3 застосуванням методу аналізу ієрархій (MAI) запропонував розглядати майбутню енергосистему через призму комбінованого процесу планування взаємодії різноманітних «акторів» [8]. Тагарт П. на засадах когнітивного моделювання розробив когнітивну модель взаємодії споживачів [4]. Ма Фанг розробив модель поведінки споживачів на засадах клітинного автомату [3]. Але залишаються недостатньо розкриті питання формування моделі поведінки 
агентів 3 питань енергозбереження (генерування, споживання, транспортування, перерозподілу), проблеми класифікації груп агентів задля підвищення забезпечить доцільність, релевантність, об'єктивність управлінських рішень, особливості впливу на групи агентів, визначення бар'єрів запровадження енергозберігаючих технологій, що обумовлені наявність групових інтересів тощо.

Постановка завдання. Метою дослідження $є$ 3'ясування основних тенденцій розвитку методологічної платформи формування системи управління енергетичного комплексу в контексті стимулювання активної поведінки агентів з питань енергозбереження; виявлення і систематизація проблем, які стримують прискорений розвиток енергетичного комплексу, їх причин та наслідків.

Методологія. У процесі дослідження використано методи теоретичного узагальнення i порівняння, аналізу і синтезу для визначення: бар'єрів групових інтересів агентів при впровадженні енергозберігаючих технологій, факторів стану агента 3 питань 3 енергозбереження, його поведінки як реалізації його інтересів. Використано теорію клітинних автоматів при формуванні математичної моделі, яка передбачає опис поведінки агентів 3 питань 3 енергозбереження у часі; модель соціальної поведінки при визначенні групи факторів, що впливають на поведінку агентів 3 питань енергозбереження.

Результати дослідження. Модернізація i інноваційний розвиток методологічної платформи формування системи управління енергетичного комплексу є достатньо важким процесом, на протязі якого необхідно постійно долати бар'єри супротиву. Умовно ці бар'єри можливо поділити на три групи: комунікаційні, промислові та технічні.

Комунікаційні бар'єри пов'язані насамперед 3 проблемою формування мотивації активної поведінки кінцевого споживача енергосистеми. Необхідно створити систему інформування споживача, його навчання новітнім цінностям енергозбереження, зменшення деструктивної поведінки щодо розташування відповідного енергетичного обладнання безпосередньо від домівок, тощо. Стимулювання споживача розширюе можливості споживання енергозберігаючих технологій, сприяє формуванню позитивного іміджу інноваційних енергозберігаючих технологій, можливостей оптимізації управління енергетикою, підвищення доступності мережі розподілу генеруючого обладнання. Значну роль в інноваційному розвитку в енергетичному комплексі, відіграють сформовані у людини життєві установки, моделі поведінки, які або сприяють поширенню інновацій, або перешкоджають. Сприйнятливість чи несприйнятливість громадянського суспільства до інновацій в сфері енергозбереження на сучасному етапі в 
Україні визначається переважно соціальними чинниками (низький рівень i якість життя значної частини населення не сприяють розвитку інновацій).

Промислові бар'єри щодо впровадження інновацій в сфері енергетичного комплексу обумовлені:

1. Низький рівень взаємодії в енергетичних компаніях: майже відсутнє співробітництво та координація дій. Відповідно, ця тенденція викликає низку проблем, що необхідно детально досліджувати як в інтересах державного регулювання цих відносин, так і в інтересах компаній, що шукають переваги від налагодження партнерських зв'язків. Таким чином, партнерські відносини є невід'ємним атрибутом життєдіяльності будь-якої енергетичної компанії, а в силу специфіки ринку, кожен повинен співпрацювати навіть 3 конкурентами. У результаті, компонента партнерства повинна бути невід'ємною складовою системи управління енергокомплексом - безпосередньо впливає на цілі, структуру та умови функціонування.

2. Проблеми невідповідності існуючого обладнання 3 елементами новітнього технологічного базису, відновної та ліквідаційної вартості обладнання - експлуатаційні витрати застарілого обладнання мінімізують капітальні витрати споживачів.

3. Стандарти суб'єктів господарювання з планування та проектування в цілому зосереджені на традиційній моделі енергетичного комплексу: централізована система генерації, технології минулого покоління, низька ймовірність переходу на активну участь споживачів у роботі енергосистеми.

4. Традиційні методи оцінювання інноваційних проектів 3 систем енергозбереження - не можливо обгрунтувати заходи енергобезпеки по відношенню до реальної або віртуальної загрози.

5. Власники та топ-менеджмент зазвичай не зацікавлені на зміну в процесах та технологіях налагодженої енергосистеми. Відсутність системи мотивації на збільшення витрат на дослідження та розробки в сукупних витратах енергетичних компаніях призводить до відставання галузі на глобальних ринках.

Розробка та впровадження інноваційних технологій потребують суттєвого прискорення за рахунок подолання технічних бар'єрів:

1. Відсутність об'єднання різноманітних технологій у енергокомплексі призводить до відсутності ефекту синергії.

2. Збільшення кількості учасників енергосистеми, зокрема електроенергетичних систем, призводять до виникненню проблем у сфери безпеки. 
3. Обмеження можливостей зберігання електроенергії: необхідно прискорити процес модернізації мережі.

4. Збільшення питомої ваги проведення технічного аналізу комп'ютерами призводить до втрат фундаментальних знань та розумінь принципів функціонування енергосистеми. Не можливість на даному етапі інформаційного суспільства створити штучний інтелект, обмеження існуючої автоматизації процесів діяльності, призводить до виникненню феномену втрат фундаментальних знань. Інвестиції носять все більш прикладний характер в галузі енергетики: орієнтація на швидкість окупності, що призводить в зменшення частоти проникнення інноваційних ідей у технологічний базис.

При реалізації моделі з енергозбереження на протязі всієї сукупності формування споживчої цінності як прояв розглянутих бар'єрів супротиву, виникають групи інтересів агентів 3 енергозбереження. Для аналізу даних процесів розглянемо математичну модель, яка передбачає опис поведінки агентів 3 питань 3 енергозбереження у часі та базується на підгрунті теорії клітинних автоматів. Клітинний автомат (КА) представляє собою сукупність однакових, деяким чином поєднаних між собою клітин, поведінка яких цілком визначається в термінах локальних залежностей $[2,6]$. При цьому стан агента 3 питань 3 енергозбереження, його поведінка як реалізація його інтересів, залежить від двох груп факторів: зовнішніх та внутрішніх. На засадах когнітивної моделювання взаємодії можливо побудувати моделі соціальної поведінки агентів на засадах соціабельності (мікросередовище) та ступеню різноманітності елементів (макросередовище).

Параметр, що характеризує дію зовнішніх факторів, позначимо $f^{e x} \in[0 ; 1]$. Зовнішні фактори можливо проаналізувати за допомогою методів стратегічного аналізу: SWOT, PEST, тощо: провести групування за факторами: економічними, політичними, соціальними, технологічними. Наприклад, до зовнішніх факторів можливо віднести: наявність пільгових споживчих кредитів, період дії «зеленого» тарифу», пільги у екологічному податку, формування ОССБ, впровадження інтернет-технологій (он-лайн лічильники), підвищення тарифів тощо [5].

До внутрішніх факторів відносяться якості кожного окремого агента 3 питань енергозбереження: здатність до комунікації, сприйнятливість до інновацій, громадянська позиція та ін. - зовнішні фактори позначимо параметром: $f^{\text {in }} \in[0 ; 1]$.

Загальну оцінку стану кожного агента 3 енергозбереження (виробника, посередника, споживача) $A \in U$ у момент часу $t$ можливо визначити таким чином: 


$$
F_{A}=f_{A}^{e x} \times f_{A}^{i n}
$$

Але 3 часом, дія зовнішніх та внутрішніх факторів змінюється 3 деякою ймовірністю $p$, відповідно і змінюється загальний стан агента:

$$
p: F_{A}(t) \rightarrow F_{A}(t+1)
$$

Агенти 3 питань енергозбереження здатні приймати рішення, що впливають на стан системи у майбутньому: існує можливість самоорганізації, адаптації. При цьому можливо згрупувати агентів за ступенем зацікавленості до процесів 3 енергозбереження, шкалювання: 0 - повна байдужість до енергозбереження; [0,1;0,4] - низький рівень зацікавленості у енергозбереженні; $(0,4 ; 0,7]$ - середній рівень зацікавленості у енергозбереженні; (0,7;1] - високий рівень зацікавленості у енергозбереженні. Ступінь зацікавленості агентів «байдужість до енергозбереження» потребує додаткового аналізу причин цієї байдужості, що обумовлена рівнем соціабельності (інертність, нонкорфомізм, рівень акомодації / асиміляції та ін.). Агентів, що входять у діапазон зацікавленості до процесів 3 енергозбереження: [0,1;1] (при цьому $U$ - всі дієздатні агенти), можливо розділити на три групи: $A$ - агенти 3 високим рівнем зацікавленості в енергозбереженні, що готові до імплементації нової моделі енергозбереження; $\bar{A}$ - агенти 3 середнім рівнем зацікавленості в енергозбереженні, необхідні додаткові зусилля для включення імплементації нової моделі енергозбереження; $\tilde{A}$ - агенти 3 низьким рівнем зацікавленості в енергозбереженні, необхідно активні заходи щодо створення та розвитку активної поведінки агентів, зменшення де структурних змін у економічній поведінки для включення імплементації нової моделі енергозбереження.

Тоді сукупність агентів 3 питань енергозбереження відображається аналітично:

$$
U=A(t) \cup \bar{A}(t) \cup \tilde{A}(t)
$$

Якщо заходи щодо створення та розвитку активної поведінки агентів 3 питань енергозбереження ефективні, відбувається розширення позитивного досвіду серед відповідних груп агентів - створюються умови для певної ймовірністі переходу із групи в групу: $\tilde{A} \rightarrow \bar{A} ; \tilde{A} \rightarrow A ; \bar{A} \rightarrow A$. При цьому ймовірність зміни стану агентів визначається, як вказане вище, $p$ : $p_{1}: \tilde{A} \rightarrow \bar{A} ; p_{2}: \tilde{A} \rightarrow A ; p_{3}: \bar{A} \rightarrow A$. Також треба зауважити, що агенти існують не в замкнутій системі: відповідно до теорії клітинних автоматів, існує вплив кожного агента, групи $(A ; \bar{A} ; \tilde{A})$ на поведінку кожного, особливо при прояві групових інтересів. На наш погляд, питання цього впливу можливо дослідити за допомогою моделі соціальної поведінки I.M. Трофімової [9]: вплив формальних ознак середовища на поведінку в групі (ступінь різноманітності 
елементів, величина популяції i можливість установлення контактів (соціабельність)). Пропонуємо визначати вплив на поведінку агентів 3 питань енергозбереження за 3 групами: 3 урахуванням ступень залучення / незалучення технічних засобів (вплив комп'ютерних соціальних мереж, активності агентів у цих соціальних мережах, рівень інформаційної прозорості засобів просування технологій 3 енергозбереження та ін.); рівень комунікативності (ментальності, сприйнятливості та інших психологічних чинників особистості); гострота проблеми 3 енергозбереження (масове відключення енергетичних систем; збільшення питомої ваги енергоносіїв у собівартості продукції, послуг, робіт; масові «вимушені канікули» в установах бюджетної сфери на опалювальний період та ін.).

Впровадження моделі поведінки агентів 3 питань енергозбереження можливо розглянути в контексті концепції «хижак-жертва», як найбільш розповсюджене явище у природі. При цьому діяльність суб'єктів господарювання розглядається у аналогії економічних систем з біологічними.

Якщо ж хижаки харчуються не здатними чинити опір видами, це призводить до іншого еволюційному результату. Гинуть ті особи, яких хижак встигає помітити. Виграють менш помітні або чим-то незручні для захоплення жертви. Еволюція видів йде в бік спеціалізації за цим ознаками [7]. Так, В.П.Романов та Б.А. Ахмадєєв запропонували описати модель взаємодії двох видів типа «хижак - жертва» у математичній формі [7]:

$$
\begin{aligned}
& \frac{d x}{d t}=(\alpha-\beta y) x, \\
& \frac{d y}{d t}=(-\gamma+\delta x) y .
\end{aligned}
$$

де $x$ - кількість жертв; $y_{-}$кількість хижаків; $t$ - час; $\alpha, \beta, \gamma, \delta$ коефіцієнти, які відображають взаємодію між видами.

Для нашого дослідження найбільший інтерес представляють саме типові хижаки у їх взаєминах з жертвами і з екосистемою в цілому. Якщо хижак харчується великими, активними жертвами - веде відбір на вдосконалення жертв, знищуючи хворих і слабких. У свою чергу, серед хижаків теж йде відбір на силу, спритність і витривалість. Наслідок у еволюційному масштабі цих відносин - прогресивне розвиток обох взаємодіючих видів - i хижака $\mathrm{i}$ жертви [2].

В економічних системах такого роду еволюція відбувається за схожими принципами. Нова технологія, особливо яка має енергозберігаючу складову, коли з'являється на ринку, потрапляє у ворожу середу і веде боротьбу за виживання (міжнародні корпорації з добутку нафти та природнього газу блокують проекти з альтернативної енергетики) [1]. Це пов'язано з тим, що на 
ринку присутні більш старі й сильні технології, тому нові технології або поглинаються старими, або вмирають, не розвинувшись в повній мірі. Але, якщо нова технологія виявляється більш конкурентною, то вона витісняє стару.

Висновки. Необхідно прискорення процесу проведення досліджень, розробок та впроваджень, збільшення співробітництва 3 науковими організаціями щодо розвитку людського та інтелектуального потенціалу, підвищення рівня розуміння та обізнаності щодо цінностей 3 енергозбереження, формування необхідних стимулів для залучення промисловості до модернізації енергосистеми. Для вирішення таких питань необхідно аналізування особливостей взаємодії групових інтересів при впровадженні енергозберігаючих технологій, розробити інструментарій аналізу, кількісного оцінювання та прогнозування розвитку процесів самоорганізації і адаптації агентів при впровадженні енергозберігаючих технологій.

Проведення даного дослідження дозволить визначити вектор та зміст взаємодії та інтереси між такими групами, як: промислове підприємство або група підприємств; інформаційно-аналітичні центри, що формують програму впровадження енергоефективних технологій та методи іiі реалізації, тобто визначають конкретні інтереси груп виробників, споживачів та ін.; організації, що надають питанню впровадження технологій використання альтернативних джерел енергії статус в загальному питанні енергозабезпечення. Доцільне використання результатів роботи при активізації діяльності такої групи дозволить посилити контроль та вплив на групи, які приймають управлінські рішення щодо доцільності заходів щодо просування технологій 3 енергозбереження.

\section{Література:}

1. Gil'orme T. Formation of the mechanism of energy efficiency management on the basis of 'predator-prey' concept / T. Gil'orme, Y. Ryzhyk, A. Yaresko // Problems of development modern science: theory and practice: Collection of scientific articles. - EDEX, Madrid, España, 2016. - P. 107-110.

2. Jobstl H.A., Hogg J.N. State of Forestry Accounting in some European Countries. In: Buttoud G., Jobstl H., Merlo M. (eds.). Accounting and Managerieal Economics for Environmentally-friendly Forestry. Economie et Sociologie Rurales, Actes et Communications, N 15, P. 1740.

3. Ma Fang. Research on Consumer Purchase Behavior Diffusion across Market Using Cellular Automata / Fang Ma, Gangling Chao, Lihua Chen, Yiping Luo // International Journal of Marketing Studies. - 2012. - Vol. 4. - № 5. - P. 108-118.

4. Thagard, P. "The Brain and the Meaning of Life" Princeton University Press, 2010. 
5. Єлісєєва О.К. Статистичне оцінювання розвитку сонячної та вітроенергетики в Україні / О.К. Єлісєєва, П.В. Хазан // Статистика України : наук.-інформ. журн. - К.: 2016: НТК статист. дослідж. - №2(76). - С.14-20.

6. Максишко Н.К. Моделі динаміки процесів самоорганізації в територіальній громаді міста / Н.К. Максишко, Я.В. Глазова // Херсонський державний університет: Економічні науки. - 2016. - Випуск 17. Частина 1. - С. 150-154.

7. Романов В.П. Моделирование инновационной экосистемы на основе модели «хищник-жертва» / В.П. Романов, Б.А. Ахмадеева // Бизнес-информатика. - № 1 (31). 2015. - C. 7-17. (9)

8. Саати Т. Л. Об измерении неосязаемого. Подход к относительным измерениям на основе главного собственного вектора матрицы парных сравнений // Журнал "Cloud Of Science". 2015. T. 2.2 № $1.2-1$ Режим доступа: (http://cloudofscience.ru/sites/default/files/pdf/CoS_2_5.pdf)

9. Трофимова И.Н. Моделирование социального поведения / И.Н. Трофимова [Электронный ресурс]. - Режим доступа: http://spkurdyumov.ru/evolutionism/modelirovaniesocialnogopovedeniya/. 